\title{
MILK PRODUCTION AND MILK COMPOSITION OF HIGH PRODUCING DAIRY COWS AS AFFECTED BY PROTECTED AND UNPROTECTED FAT SUPPLEMENTATION
}

\author{
A.M. Salleem'; A.K.I. Abd El-Moty²; M.A.A. El-Barody²; A.A. Abd El-Hakeam²; A.A. \\ Bayoumi $^{1}$ and V. Fellner ${ }^{3}$ \\ ${ }^{1}$ Animal Production Department, Faculty of Agriculture, South Valley University, Assiut, Egypt. \\ ${ }^{2}$ Animal Production Department, Faculty of Agriculture, Minia University, Minia, Egypt. \\ ${ }^{3}$ College of Agriculture and Life Science, North Carolina State University, USA.
}

\section{SUMMARY}

$\mathrm{T}$ This study was conducted at North Carolina State University, USA. Primiparous $(\mathrm{n}=9)$ and multiparous ( $\mathrm{n}=17$ ) Holstein cows were utilized in a completely randomized block design. Three treatments were as follows : (1) control treatment ( $\mathrm{CON}$ ) without fat supplementation ; (2) unprotected fat treatment (UF), which fat supplemented as soybean oil; (3) protected fat (PF), which fat supplemented as Megalac. Fats were supplemented to the cows diets beginning at 21 days prior to expect calving date through 60 days postpartum. Supplemental fats were fed at $2 \%$ and $3 \%$ dietary dry matter (DM) during prepartum and postpartum periods, respectively. Milk production measured daily. Milk fat, protein, lactose and solids not fat (SNF) were analyzed at day 0, 30 and 60 postpartum. The results indicated that, prepartum dry matter intake (DMI) was not significantly different across treatments. However, fat supplementation decreased postpartum DMI compared to the CON treatment. Cows fed PF beginning in the prepartum period produced more milk and higher FCM than cows fed UF and CON treatments. Feeding PF numerically increased milk fat percentage compared to the CON and UF diets, but the difference was not significant among treatments. However, PF treatment tended to decreased $(\mathrm{P}=0.10)$ milk protein percentage compared to CON and UF treatments. Feeding fat did not alter milk lactose and solids not fat percentages in comparison with CON diet. Feed efficiency, expressed as kg of $3.5 \%$ FCM per $\mathrm{kg}$ of DM intake, was significantly higher when feeding fat treatments than feeding CON. Concentration of C8:0 in milk fat tended to be higher $(\mathrm{P}=0.10)$ in cows fed fat compared to $\mathrm{CON}$ treatment. Fat supplementation had no significant effect on production of $\mathrm{C} 12: 0, \mathrm{C} 14: 0, \mathrm{C} 15: 0, \mathrm{C} 18: 1$ and $\mathrm{C} 18: 2$ in milk fat . However, significant differences were found in C10:0, C16:0 and C18:0 in UF and PF treatments compared to CON treatment. From the present results it can be concluded that supplementation of protected fat in the rations of high producing dairy cows during prepartum and postpartum led to positive effect on milk production and milk composition.

Keywords: Milk production, milk composition and protected fat.

\section{INTRODUCTION}

Extensive mobilization of body fat is a key factor in meeting energy demands in early lactation of high producing dairy cows. Fat supplementation during prepartum and postpartum periods is a strategy that has been evaluated to enhance productive performances of high producing dairy cows. Addition of fat to the diet of high producing dairy cows may improve their energy status and increase energy supply. Milk yield (Salado et al., 2004; Tyagi et al., 2010 and Reis et al., 2012) and milk fat concentration (Titi and Obeidat, 2008) have increased by addition of fat in the diet. The ruminal microorganisms transform unsaturated fatty acids in a process called biohydrogenation to saturated end products. Therefore, delivery of unsaturated fatty acids to the mammary tissue is limited even when their dietary concentration is high (Jenkins and McGuire, 2006). There is considerable interest in finding ways to protect dietary unsaturated fatty acids from biohydrogenation to enhance their absorption and delivery to the mammary gland. Nutritionists commonly recommend feeding dairy cows calcium salt of fatty acid, protected against ruminal biohydrogenation by microbes to modify milk fatty acid composition (Lounglawan et al., 2008 and Purushothaman et al., 2008). The aim of this study investigated the effect of fat supplementation (protected and unprotected) during prepartum and postpartum periods on milk production and its composition. 


\section{MATERIALS AND METHODS}

\section{Experimental design:}

Experiment was conducted at North Carolina State University (USA). Periparturient Holstein primiparous $(n=9)$ and multiparous cows $(n=17)$ were classified into three groups by predicted calving date, parity (primiparous or multiparous), body weight and milk production of the previous year for multiparous cows. Cows were randomly assigned to three treatments at approximately $21 \pm 5$ days prior to their expected calving data.

The cows were fed the experimental dry cows diets and fed lactating cows diets from calving until 60 day after calving. Three diets were prepared and fed individually as a total mixed ration (TMR) in adlibitum amounts once daily at 11:00 a.m. Individual dry matter intake (DMI) was measured daily. Cows were fed to cover the requirement of dry matter (DM) and total digestible nutrient (TDN) according to NRC (2001) and the rations were adjusted biweekly. Each group of cows was randomly assigned to one of the three experimental treatments as the following: 1) control treatment (CON, 8 Cows) without fat supplementation; 2) unprotected fat treatment (UF, 9 Cows) which fat supplemented as soybean oil; 3) protected fat (PF, 9 Cows ) which fat supplemented as calcium salt of long chain fatty acids (CSLCFA, Megalac $^{\circledR}$ ). Supplemental fats were added at $2 \%$ and $3 \%$ of dietary DM during prepartum and postpartum periods, respectively. The basal diet during the prepartum period consisted of: corn silage, normal oats silage, soybean hulls, whole cottonseed and concentrate mixture. The basal diet during the postpartum period consisted of: corn silage, normal oats silage, whole cottonseed, soybean hulls, corn gluten feed and concentrate mixture. Fat was added at the top of the fat treatments separately for each individual cow diet for complete consumption of supplemental fat.

\section{Samples collection and analysis:}

\section{Diets samples:}

Representative samples of the experimental diets were collected on a weekly basis and composited on a monthly basis. Representative samples were analyzed for DM, CP, EE, NDF, ADF, NFC, Ca, P and TDN (Table, 1) according to AOAC (1990).

Table (1). Proximate analysis and TDN of experimental diet fed to Holstein cows during experimental period.

\begin{tabular}{|c|c|c|c|c|c|c|c|c|c|}
\hline \multirow{2}{*}{ Item } & \multicolumn{8}{|c|}{ Proximate analysis } & \multirow{2}{*}{ TDN } \\
\hline & $\mathrm{DM}$ & $\mathrm{CP}$ & $\mathrm{NDF}$ & ADF & $\mathrm{EE}$ & $* \mathrm{NFC}$ & $\mathrm{Ca}$ & $\mathrm{P}$ & \\
\hline Prepartum & 31.47 & 14.89 & 53.2 & 34.19 & 3.08 & 22.75 & 0.43 & 0.25 & 64.73 \\
\hline Pospartum & 53.70 & 17.12 & 37.67 & 25.71 & 3.15 & 33.33 & 0.67 & 0.49 & 72.46 \\
\hline
\end{tabular}

$* N F C=$ Non fiber carbohydrate.

1- Fat was added separately to the UF and PF treatments and chemical composition does not reflect addition of fat. 2- $C P, N D F, A D F, E E, N F C, C a, P$ and TDN \% of DM.

\section{Milk samples:}

All cows were milked twice daily at 07:00 and 18:00 h. Milk yield was recorded individually at each milking time. Individual milk samples from consecutive a.m. and p.m. milkings were collected on week 1 (days 0), week four (day 30), and week 8 (day 60) postpartum and composited according to milk weight at each milking time ( $3 \mathrm{~mL} / \mathrm{kg}$ milk at each milking time). One aliquot of $10 \mathrm{~mL}$ composite samples were analyzed individually for fat, protein and solid not fat. Milk fat, protein, lactose and solid not fat (SNF) yields were calculated by multiplying milk yield from the respective day by fat, protein, lactose and SNF content of the milk for an individual cow. Another aliquot of the milk samples was frozen at $-20^{\circ} \mathrm{C}$ for fatty acids (FA) determination. Weighted composite milk samples from a.m. and p.m. milkings at day 60 postpartum were analyzed for fatty acid (FA) composition using gas-liquid chromatography according to (Kramer et al., 1997). Fat-corrected milk (FCM; 3.5\%) was calculated according to Tyrrell and Reid (1965) by using the following equation:

$$
3.5 \% \text { FCM }(\mathrm{kg} / \text { day })=(16.22 \text { milk fat, } \mathrm{kg} / \text { day })+(0.43 \text { milk yield, } \mathrm{kg} / \text { day })
$$




\section{Statistical analysis:}

Data for milk production, milk constituents and milk fatty acid composition were analyzed according to a randomized complete block design using SAS (2005). Results were presented as least square means \pm standard error of the mean.

\section{RESULTS AND DISCUSSION}

\section{Dry matter intake (DMI):}

The present results (Table, 2) showed that prepartum DMI was not significantly different among the dietary treatment groups. This may be due to the low amount of fat ( $2 \%$ of dietary DM) offered to experimental cows during the prepartum period. Many studies have reported no changes in dry matter intake with supplemental fat (Andersen et al., 2008; Castañeda-Gutiérrez et al., 2009; Tyagi et al., 2010 and Shelke et al., 2012). Other studies have reported a decrease in dry matter intake (DMI) with supplemental fat (Moallem et al., 2007a and Moallem et al., 2010). During the postpartum period, dry matter intake was significantly higher $(P<0.0001)$ in cows fed the CON treatment without any fat supplementation than those cows fed the fat treatments (Table 2). A comparison between fat treatments showed that cows fed PF supplemented diet had significantly lower $(P<0.05))$ dry matter intakes than cows fed UF treatment. In addition, postpartum dry matter intake expressed as \% of BW showed lower values in PF and UF groups compared to CON group. In a review of several studies Moallem et al., (2007b); Purushothaman et al., (2008); Tyagi et al., (2010), Shelke et al., (2012) and Ganjkhanlou et al., (2009) reported that DMI was decreased with supplementation of rumen protected fat to the lactating cows diets compared to control diet. Variation in response to adding fat to the diets can be dependent on the type and amount of fat added and stage of lactation.

Table (2). Dry matter intake (DMI) and postpartum body weight (BW) of Holstein cows fed control diet (CON) or diets supplemented with unprotected fat (UF) or protected fat (PF).

\begin{tabular}{|c|c|c|c|c|c|c|}
\hline \multirow[t]{2}{*}{ Item } & \multicolumn{3}{|c|}{ Treatments } & & \multicolumn{2}{|c|}{ Contrast, $P$ values } \\
\hline & $\mathrm{CON}$ & UF & $\mathrm{PF}$ & SEM & CON vs. FAT & UF vs. PF \\
\hline $\begin{array}{l}\text { Measurements } \\
\text { DMI (kg/day) }\end{array}$ & & & & & & \\
\hline Prepartum & 7.97 & 7.79 & 7.75 & 0.19 & 0.56 & 0.54 \\
\hline $\begin{array}{l}\text { Postpartum } \\
\text { DMI (\%BW) }\end{array}$ & 20.41 & 18.87 & 17.99 & 0.23 & $<.0001$ & 0.005 \\
\hline Postpartum & 3.82 & 3.68 & 3.38 & 0.04 & $<.0001$ & $<.0001$ \\
\hline
\end{tabular}

\section{Milk yield:}

In the present study, cows fed PF treatment beginning at prepartum period (21 day before calving) through the first 60 days in milk produced $18 \%$ and $15 \%$ more milk yield than CON and UF treatments, respectively (Table, 3). In addition, milk yield of UF cows was higher than milk yield of CON cows. Generally, significant differences in milk yield and 3.5\% FCM were detected among cows fed CON and those cows fed fat (UF and PF). Supporting to our results, the previous studies also reported enhanced milk production (Salado et al., 2004 and Reis et al., 2012) when Ca salts of fatty acids were offered to dairy cows. The superiority of milk yield in added fat groups may be attributed to that fat supplementation increasing the energy density of the diets in which resulting in reducing the negative effect of negative energy balance. In addition, feeding PF during the prepartum period increased after parturition milk production may be due to increase energy intake and minimal stress of adjusting to a new dietary ingredient early in lactation. The present results are in agreement with the findings of $\mathrm{Bu} e t \mathrm{al}$., (2007); Tyagi et al., (2010) and Shelke et al., (2012) showed that supplementation of bypass fat increased milk production when compared to control diet and this may be due to bypass fat supplementation increased the energy density of the ration and resulting in reducing the deleterious effect of negative energy balance. However, other studies (Aguilar-Pérez et al., 2009 and Ganjkhanlou et al., 2009) showed no effect of fat supplementation on milk production of high producing dairy cows .

Feed efficiency: 
Feed efficiency, expressed as $\mathrm{kg}$ of $3.5 \%$ FCM per $\mathrm{kg}$ of DM intake was significantly higher when feeding fat treatments than feeding CON treatment (Table, 3). In addition, a significant difference was found between UF and PF treatments. These results suggest that cows fed fat supplementation were more able to efficiently convert feed nutrients into milk. The present study are in agreement with those of Ganjkhanlou et al., (2009) and Moallem et al., (2010).

Table (3). Milk yield, feed efficiency and milk composition of lactating Holstein cows fed control diet (CON) or diets supplemented with unprotected fat (UF) or protected fat (PF).

\begin{tabular}{|c|c|c|c|c|c|c|}
\hline \multirow[t]{2}{*}{ Item } & \multicolumn{3}{|c|}{ Treatments } & & \multicolumn{2}{|c|}{ Contrast, $P$ values } \\
\hline & $\mathrm{CON}$ & UF & $\mathrm{PF}$ & SEM & CON vs. FAT & UF vs. PF \\
\hline \multicolumn{7}{|l|}{ Measurements: } \\
\hline Milk yield, kg/d & 27.80 & 28.47 & 32.70 & 0.60 & 0.0003 & $<.0001$ \\
\hline $3.5 \%$ FCM, kg/d & 26.94 & 27.08 & 34.34 & 0.59 & $<.0001$ & $<.0001$ \\
\hline Feed efficiency & 1.42 & 1.60 & 2.03 & 0.32 & $<.0001$ & $<.0001$ \\
\hline \multicolumn{7}{|l|}{ Milk composition: } \\
\hline \multicolumn{7}{|l|}{ Milk fat, } \\
\hline$\%$ & 3.27 & 3.20 & 3.81 & 0.30 & 0.51 & 0.18 \\
\hline$(\mathrm{Kg} / \mathrm{d})$ & 0.91 & 0.91 & 1.25 & 0.02 & $<.0001$ & $<.0001$ \\
\hline \multicolumn{7}{|l|}{ Milk protein, } \\
\hline$\%$ & 2.91 & 2.99 & 2.79 & 0.08 & 0.87 & 0.10 \\
\hline$(\mathrm{Kg} / \mathrm{d})$ & 0.81 & 0.85 & 0.92 & 0.02 & 0.001 & 0.01 \\
\hline \multicolumn{7}{|l|}{ Lactose } \\
\hline$\%$ & 4.78 & 4.69 & 4.69 & 0.08 & 0.36 & 0.99 \\
\hline$(\mathrm{Kg} / \mathrm{d})$ & 1.34 & 1.34 & 1.53 & 0.03 & 0.005 & $<.0001$ \\
\hline \multicolumn{7}{|l|}{ SNF } \\
\hline$\%$ & 8.62 & 8.60 & 8.41 & 0.11 & 0.40 & 0.22 \\
\hline$(\mathrm{Kg} / \mathrm{d})$ & 2.41 & 2.45 & 2.75 & 0.05 & 0.003 & $<.0001$ \\
\hline
\end{tabular}

\section{Milk fat content:}

No significant differences were found in milk fat percentage among groups, although value of concentration of fat was numerically higher in milk from PF cows than in milk from CON or UF cows (Table, 3). Milk fat content was $17 \%$ and $19 \%$ greater for cows fed PF treatment versus CON and UF treatments, respectively. The observed decrease in milk fat content in CON and UF treatments are generally attributed to altered rumen function, biohydrogenation of unsaturated fat sources and ruminal fermentation (Bauman and Griinari, 2003). Also, Zheng et al., (2005) observed that milk fat percentage was lower when cows received supplemental soybean oil diet than control diet. Milk fat yields were greater for cows fed PF treatment than those cows fed CON or UF treatments. Milk fat yield of PF cows was higher than milk fat yield of CON or UF cows. The higher fat production observed in cows fed PF treatment may be explained by higher milk production.

\section{Milk protein content:}

Milk protein percentage did not significantly differ among cows fed CON and those cows fed the two fat treatments (Table, 3). However, milk protein percentage tended to decrease $(P=0.10)$ when cows received PF treatment compared to cows receiving UP treatment. The change may be attributed to increase in milk yield rather than decrease in milk protein synthesis (Appeddu et al., 2004; Schroeder et al., 2004). Generally, Petit et al., (2007) and Reis et al., (2012) reported that milk protein concentration did not decrease when fat was added to lactating cows diets. In addition, previous studies have reported no effect of soybean oil supplementation on milk protein content (Zheng et al., 2005; Bu et al., 2007). In another study Afzalzadeh et al., (2010) revealed that feeding fat at prepartum period may help animals to use fat sources for energy requirements and consequently other sources of energy such as amino acids (glucogenic precursors) could be used for other functions like protein synthesis and milk production. Likely due to increase milk production, milk protein yield was significantly $(P<0.05)$ greater by cows fed fat treatments than cows fed CON treatment. In addition, a significant difference $(P<0.05)$ was observed in milk protein yield between cows fed the two fat treatments. 


\section{Milk lactose and solids not fat (SNF) contents:}

Concentrations of milk lactose and SNF were not significantly different among treatments, whereas yields of milk lactose and SNF were significantly $(P<0.05)$ higher for cows fed fat treatments than those cows fed CON. This may be due to the difference in milk yield among all treatments (Table, 3 ). The present results are in agreement with those reported by Afzalzadeh et al., (2010) and Shelke et al., (2012).

\section{Milk fatty acid composition:}

Fatty acids composition of milk as affected by the different treatments groups are presented in Table (4). The production of fatty acids with 14 carbons or less and 50\% of C16:0 formations is a result of de novo fatty acid synthesis in the mammary gland and from mammary uptake of preformed fatty acids. Fat source, time of initiation of the supplementation, inclusion rate, period length of supplementation and biohydrogenation extent will differentially affect the incorporation of the long chain fatty acids into milk fat of dairy cows. The depression of these fatty acids can be explained by inhibitory roles of fat supplementation on fiber digestion and de novo fatty acid synthesis (Gaynor et al., 1995). Concentration of C8:0 in milk fat tended to be higher $(P=0.10)$ in cows fed the fat treatments than the CON treatment. Fat supplementation had no significant effect on production of C12:0, C14:0, C15:0, C18:1 and C18:2 in milk fat. However, significant differences in C10:0, C16:0 and C18:0 when compared to CON treatment. A comparison between fat treatments showed that addition of PF to the ration increased the proportion of saturated fatty acids from $\mathrm{C} 8$ to $\mathrm{C} 16$ and decreased the proportions of $\mathrm{C} 18: 0, \mathrm{C} 18: 1$ and $\mathrm{C} 18: 2$ in milk fat compared to UF treatment. Increase level of C16:0 in milk fat of cows fed PF treatment may be due to the fact that the protected fat (PF) consisted mainly of palm oil fatty acids (C16). Increased levels of unsaturated fatty acids in the milk can only occur when unsaturated fatty acids present in feed or supplements escaped microbial action in the rumen. Concentration of C18:2 and C18:3 were decreased when fat was added to the diets (Onetti et al., 2001). The low concentration of C18:2 and C18:3 in cows fed $\mathrm{Ca}$ salts of unsaturated fatty acids may be as a result of Ca salts dissociating in the rumen and fatty acids being saturated by ruminal microorganisms (Chouinard et al., 1998). In another study, Warntjes et al., (2008) showed that cows fed rumen inert fat as palmitic acid (C16:0) led to increase concentration of C16:0 in milk fat and decreased concentration of C17:0 and C18:0. However, concentration of C18:2 was not affected when compared to the control diet. Obeidat et al., (2011) reported that except C18:1 and C 20:0 dietary treatments had no effects on profile of short or medium chain fatty acids when lactating ewes were fed control or fat supplemented diets. The increase in C18:1 can be the result of partial biohydrogenation of C18:2 and C18:3 FA and desaturation of C18:0 in the mammary gland (Kennelly, 1996). However, Warntjes et al., (2008) reported a decrease in milk short and medium chain fatty acids with palmitic acid (C16:0) supplementation. The authors attributed that C16:0 in the diet may have decreased de novo synthesis of short and medium chain FA in the mammary gland. In the present study, the data revealed that there was no negative effect of PF supplementation on short or medium chain fatty acids.

Table (4). Milk fat fatty acids composition of lactating Holstein cows fed control diet (CON) or diets supplemented with unprotected fat (UF) or protected fat (PF).

\begin{tabular}{|c|c|c|c|c|c|c|}
\hline \multirow{2}{*}{$\begin{array}{l}\text { Item, } \% \text { of total fatty } \\
\text { acids }\end{array}$} & \multicolumn{3}{|c|}{ Treatments } & \multicolumn{3}{|c|}{ Contrast, $P$ values } \\
\hline & $\mathrm{CON}$ & UF & $\mathrm{PF}$ & SEM & $\begin{array}{l}\text { CON vs. } \\
\text { FAT }\end{array}$ & UF vs. PF \\
\hline \multicolumn{7}{|l|}{ Fatty Acids } \\
\hline Caprylic acid (C8:0) & 0.24 & 0.50 & 0.57 & 0.13 & 0.10 & 0.71 \\
\hline Capric acid (C10:0) & 0.72 & 1.29 & 1.95 & 0.28 & 0.02 & 0.12 \\
\hline Lauric acid (C12:0) & 1.74 & 1.52 & 2.13 & 0.29 & 0.81 & 0.16 \\
\hline Myristic acid (C14:0) & 6.99 & 7.21 & 8.02 & 0.96 & 0.61 & 0.56 \\
\hline Pentadecylic acid (15:0) & 0.64 & 0.56 & 0.63 & 0.14 & 0.80 & 0.72 \\
\hline Palmitic acid (C16:0) & 27.45 & 27.39 & 35.69 & 1.24 & 0.02 & 0.0003 \\
\hline Stearic acid (C18:0) & 19.59 & 17.72 & 14.65 & 1.33 & 0.06 & 0.12 \\
\hline Oleic acid (C18:1) & 36.56 & 37.65 & 31.50 & 1.67 & 0.36 & 0.02 \\
\hline Linoleic acid (C18:2) & 4.58 & 4.55 & 4.02 & 0.56 & 0.68 & 0.52 \\
\hline
\end{tabular}


From the present study, it can be concluded that the supplementation of fat during prepartum and postpartum specially protected fat led to positive effects on milk production and milk composition. SEM $=$ standard error of the mean.

\section{REFERENCES}

Afzalzadeh, A.; M.H. Palizdar; H. Mahmoudzadeh and A. Niasari-Naslaji (2010). Effect of fat supplementation during transition period on plasma leptin and non-esterified fatty acid concentrations in Holstein cows. Anim. Sci. J., 81:309-315.

Aguilar-Pérez, C.; J. Ku-Vera and P.C. Garnsworthy (2009). Effects of bypass fat on energy balance, milk production and reproduction in grazing crossbred cows in the tropics. Livestock Science, 121:6471.

Andersen, J.B.; C. Ridder and T. Larsen (2008). Priming the cow for mobilization in the periparturient period: Effects of supplementing the dry cow with saturated fat or linseed. J. Dairy Sci., 91:10291043.

Appeddu, L.A.; D.G. Ely; D.K. Aaron; W.P. Deweese and E. Fink (2004). Effects of supplementing with calcium salts of palm oil fatty acids or hydrogenated tallow on ewe milk production and twin lamb growth. J. Animal Sci., 82:2780-2789.

AOAC (1990). Association of Official Analytical Chemists. Official Methods of Analysis. 15th Edition Arlington VA, USA.

Bauman, D.E. and J.M. Griinari (2003). Nutritional regulation of milk fat synthesis. Annu. Rev. Nutr., 23:203-227.

Bu, D.P.; J.Q. Wang; T.R. Dhiman and S.J. Liu (2007). Effectiveness of oils rich in linoleic and linolenic acids to enhance conjugated linoleic acid in milk from dairy cows. J. Dairy Sci., 90:998-1007.

Castañeda-Gutiérrez, E.; S.H. Pelton; R.O. Gilbert and W.R. Butler (2009). Effect of peripartum dietary energy supplementation of dairy cows on metabolites, liver function and reproductive variables. Anim. Reprod. Sci., 112:301-315.

Chouinard, P.Y.; V. Girard and G.J. Brisson (1998). Fatty acid profile and physical properties of milk fat from cows fed calcium salts of fatty acids with varying unsaturation. J. Dairy Sci., 81:471-481.

Ganjkhanlou, M.; K. Rezayazdi; G.R. Ghorbani; M. Dehghan Banadaky; H. Morraveg and W.Z. Yang (2009). Effects of protected fat supplements on production of early lactation Holstein cows. Anim. Feed Sci. and Tech., 154:276-283.

Gaynor, P.J.; D.R. Waldo; A.V. Capuco; R.A. Erdman; L.W. Douglass and B.B. Teter (1995). Milk fat depression, the glucogenic theory, and trans-C18:1 fatty acids. J. Dairy Sci., 78:2008-2015.

Jenkins, T.C. and M.A. McGuire (2006). Major advances in nutrition: Impact on milk composition. J. Dairy Sci., 89:1302-1310.

Kennelly, J.J. (1996). The fatty acid composition of milk fat as influenced by feeding oilseeds. Anim. Feed Sci. and Tech., 60:137- I52.

Kramer, J.K.G.; V. Fellner; M.E.R. Dugan; F.D. Sauer; M.M. Mossoba and M.P. Yurawecz (1997). Evaluating acid and base catalysts in the methylation of milk and rumen fatty acids with special emphasis on conjugated dienes and total trans fatty acids. Lipids, 32:1219-1228.

Lounglawan, P., K. Chullanandana and W. Suksombat (2008). The effect of hydrogenated fat or Ca-salt of fatty acids on milk yield composition and milk fatty acids of dairy cows during mid lactation. Thai J. Agric. Sci., 41(1-2):29-36.

Moallem, U.; G. Altmark; H. Lehrer and A. Arieli (2010). Performance of high-yielding dairy cows supplemented with fat or concentrate under hot and humid climates. J. Dairy Sci., 93:3192-3202.

Moallem, U.; M. Katz; A. Arieli and H. Lehrer (2007a). Effects of peripartum propylene glycol or fats differing in fatty acid profiles on feed intake, production, and plasma metabolites in dairy cows. J. Dairy Sci., 90:3846-3856. 
Moallem, U.; M. Katz; H. Lehrer; L. Livshitz and S. Yakoby (2007b). Role of peripartum dietary propylene glycol or protected fats on metabolism and early postpartum ovarian follicles. J. Dairy Sci., 90:1243-1254.

NRC (2001). National Research Council. Nutrient Requirements of Dairy Cattle. 7th Rev. Ed., Natl. Acad. Press, Washington, DC.

Obeidat, B.S.; M.S. Awawdeh; H.H. Titi; A.A. Abughazaleh F.A. Al-Lataifeh I.A. Alawneh, M.A. Abu Ishmais; R.I. Qudsieh and H.S. Subih (2011). Effect of feeding calcium salts on performance of nursing Awassi ewes. Trop. Anim. Health Prod., 43:1211-1217.

Onetti, S.G.; R.D. Shaver; M.A. McGuire and R.R. Grummer (2001). Effect of type and level of dietary fat on rumen fermentation and performance of dairy cows fed corn silage-based diets. J. Dairy Sci., 84:2751-2759.

Petit, H.V.; M.F. Palin and L. Doepel (2007). Hepatic lipid metabolism in transition dairy cows fed flaxseed. J. Dairy Sci., 90:4780-4792.

Purushothaman, S.; A. Kumar and D.P. Tiwari (2008). Effect of feeding calcium salts of palm oil fatty acids on performance of lactating crossbred cows. Asian-Aust. J. Anim. Sci., 12:376-385.

Reis, M.M.; R.F. Cooke; J. Ranches and J.L.M. Vasconcelos (2012). Effects of calcium salts of polyunsaturated fatty acids on productive and reproductive parameters of lactating Holstein cows. J. Dairy Sci., 95:1-12.

Salado, E.E.; G.A. Gagliostro; D. Becu-Villalobos and I. Lacau-Mengido (2004). Partial replacement of corn grain by hydrogenated oil in grazing dairy cows in early lactation. J. Dairy Sci., 87:1265-1278.

SAS/STAT. Software (2005). Changes and Enhancements Through Release 9.1. SAS Inst., Inc., Cary, $\mathrm{NC}$.

Schroeder, G.F.; G.A. Gagliostro; F. Bargo; J.E. Delahoy and L.D. Muller (2004). Effects of fat supplementation on milk production and composition by dairy cows on pasture: a review. Livestock Prod. Sci., 86:1-18.

Shelke, S.K.; S.S. Thakur and S.A. Amrutkar (2012). Effect of feeding protected fat and proteins on milk production, composition and nutrient utilization in Murrah buffaloes (Bubalus bubalis). Anim. Feed Sci. and Tech., 171:98-107.

Titi, H.H. and B.S. Obeidat (2008). Effects of Ca salt supplementation on milk yield and composition and on lamb growth rate of Awassi ewes. Livest. Sci., 119:154-160.

Tyagi, N.; S.S. Thakur and S.K. Shelke (2010). Effect of bypass fat supplementation on productive and reproductive performance in crossbred cows. Trop. Anim. Health Prod., 42:1749-1755.

Tyrrell, H.F. and J.T. Reid (1995). Prediction of the energy value of cow's milk. J. Dairy Sci., 48:12151223.

Warntjes, J.L.; P.H. Robinson; E. Galo; E.J. DePeters and D. Howes (2008). Effects of feeding supplemental palmitic acid (C16:0) on performance and milk fatty acid profile of lactating dairy cows under summer heat. Anim. Feed Sci. and Tech., 140:241-257.

Zheng, H.C.; J.X. Liu; J.H. Yao; Q. Yuan; H.W. Ye; J.A. Ye and Y.M. Wu (2005). Effects of dietary sources ovegetable oils on performance of high-yielding lactating cows and conjugated linoleic Acids in milk. J. Dairy Sci., 88:2037-2042. 
انتاج وتركيب اللبن في الابقار عالية الادرار نتيجة اضافة الدهن الدحمى وغير المحمي

محمد عاطف سليم1، عبدالمعطى خيري ابراهيم 2، محمد عبدالقتاح البارودى2، عبدالهادى عبدالحكيم، احمد عبدالجليل بيومى 1 و فيفك فيلنر 3

اكلية الزراعة - قسم الانتاج الحيوانى - جامعة جنوب الوادى - مصر.

علية الزراعة - قسم الانتاج الحيوانسى - جامعة المنيا - مصر.

3حلية الزراعة وعلوم العياة -جامعة كارولينا- الولايات المتصدة الامريكية.

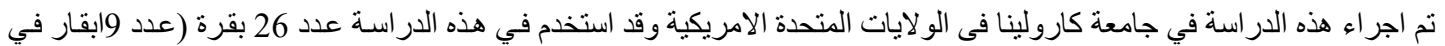

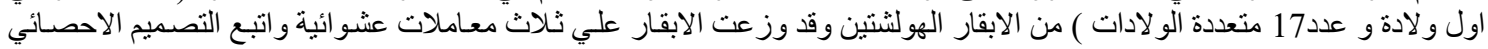

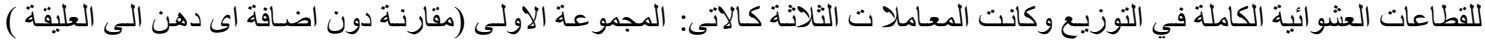

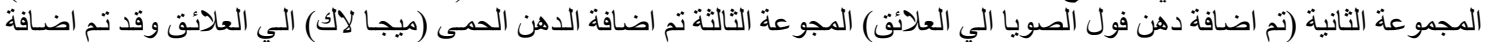

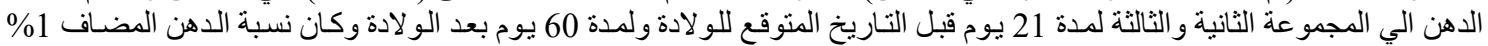

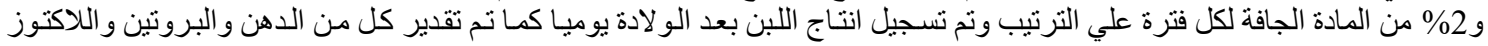

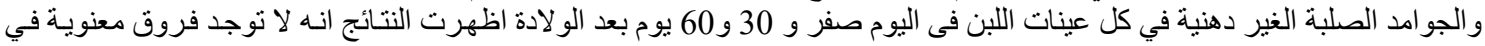

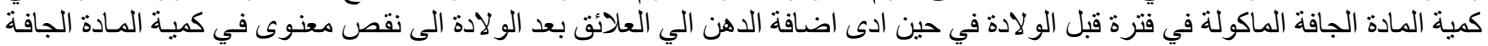

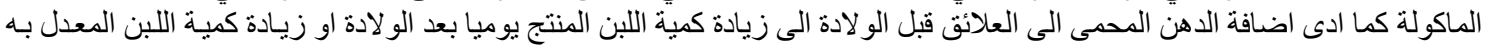

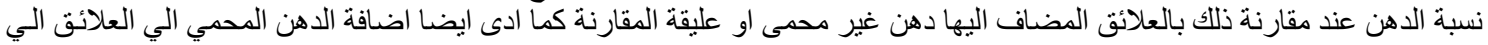

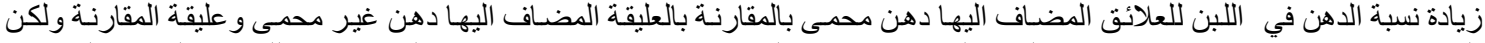

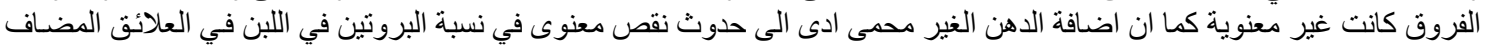

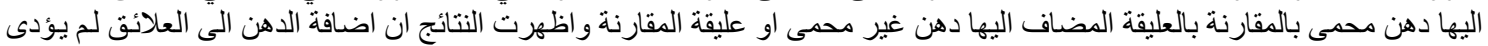

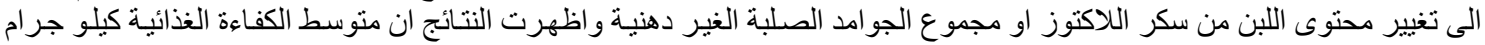

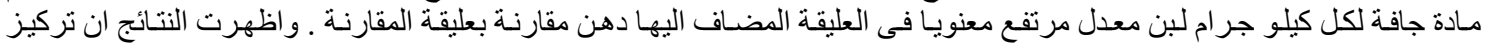

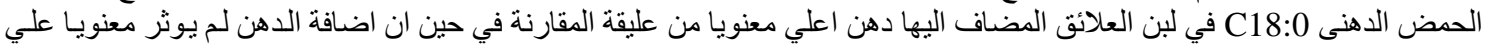

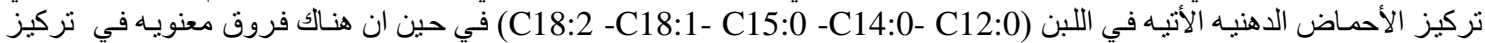

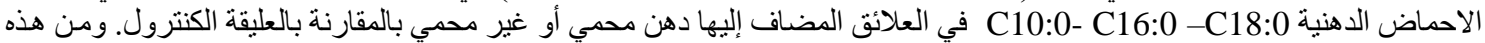
النتائج نستخلص ان اضافة الدهن المحمى الي علائق الابقار عالية الادرار ادى الي تانثير اليجابى علي كمية اللبن وتركيبة. 